\title{
Search for the New Strategy Vision for Russia: Problems, Restrictions, Opportunities
}

\author{
Yuri N. Moskvich* \\ Krasnoyarsk State Pedagogical University \\ named after V.P. Astafyev \\ 89 Ada Lebedeva Str., Krasnoyarsk, \\ 660049, Russia
}

Received 21.01.2017, received in revised form 14.02.2017, accepted 22.03.2017

Newrestrictions on the possibility of effective forecasting and planning of the future and use of traditional technologies for developing strategies, due to the high rate of generation of scientific knowledge and related technological changes are analysed and discussed. The reasons for the instability of traditional management systems, irrationality and ineffectiveness of management decisions are considered. Basic foundations of optimistic development strategies and necessary procedures for their coordination of interests are proposed.

Keywords: strategic management, decision-making systems, vision of the future, picture of the world, world outlook, technological revolution, modernization of education, human, social and cultural capital.

DOI: $10.17516 / 1997-1370-0063$.

Research area: culture studies.

\section{Introduction}

In modern Russia, future is becoming a more and more acute topic for discussions. On one hand, it's time. After 25 years of difficulties and reformations, the new generations of Russia need a certain project of the future. It has been convincingly proven by the research carried out among students, entrepreneurs and expert groups of Krasnoyarsk ${ }^{1,2}$. The overwhelming majority of students $(89 \%$ of science students and $83.3 \%$ of humanities students) would like to have a project of the future for our country. On the other hand, the global economic crisis and unexpected anticipation of the fourth technological revolution ${ }^{3}$ have aggravated the issue of Russia's nearest future to its ultimate extreme. As a mechanism for the development of future images and ways of bringing them to life, we chose the concept language of strategic corporation management which has proven to be convenient for modern Russian economists, politicians and people of power ${ }^{4}$. Within this approach, strategic management is understood as development and performance of some actions leading to the long-term increase of a company's efficiency in comparison with its

(C) Siberian Federal University. All rights reserved

* Corresponding author E-mail address: yumoskvich@mail.ru 
competitors, while strategy is understood as a set of organizational actions and management approaches, used for the performance of organizational tasks and purposes, which means, in this particular case, the organizational tasks and purposes of the whole country. Obviously, it is not easy to handle such a multifaceted task in the continuously changing world. We can see it in the process of preparation of a development strategy for Russia (several deadlines for it have already passed. Several more projects of strategy for the Krasnoyarsk Territory (Krai), one of the key regions of the country, have also been put off. A new project ${ }^{5}$ which, according to the authors, is expected to get included into the general Russian strategy, does not cause much enthusiasm of the regional elite and may be also put on the back burner. But will its time ever come? What is the reason? This article presents an attempt to analyse the current situation, problems and restrictions of strategic forecasting and planning.

\section{The World Today}

Doubtlessly, the world we live in today has become even more complicated and less predictable it has ever been. The euphoria of the cornucopia brought by the technological revolutions is gradually turning into universal anxiety. The number of "major problems" has considerably grown in the last 40 years, and, according to K.K. Kolin, it has reached fifty, while new and new threats keep capturing all spheres of our lives, including the relationships of man and nature, social behaviour and development of man himself ${ }^{6}$. The key peculiarity of the new manmade world is its self-sufficiency, specificity, independence of its creators. As a man-made planetary intellectual machine, globalization is getting out of control of its creators and doers? High speed and density of economic and social changes creates lots of uncertainties in the evaluation of development trends. The emerging pictures of the world appear ephemeral, virtual ${ }^{8}$. The former stable vision of the world is fading away. The forecasts based on rapidly dating theoretical knowledge are replaced with a game of chance, intrigues, coincidence of a large number of development factors. In many ways, the new world is becoming similar to a turbulent world, the management laws of which we still have to discover.

The source for the expanding changes is new human knowledge and technologies based on it. The well-known researcher R. Crawford prophesized the new role of knowledge and technologies in the world destiny back in the $90 \mathrm{~s}$ of the past century: "new knowledge leads to new technology, which in turn leads to economic changes, which in turn leads to social and political change, which ultimately creates a new paradigm or world view". Consequently, the cause for the accelerating global turbulence is the increasing quality of education and the accelerating generation of scientific knowledge used in useful, undeniable innovations. The running wheel of global changes, launched with the universal education and technological progress, cannot but go even faster.

It is possible to overtake the process only for the people able to get control over this continuously updating habitat, turning the turbulent world emerging upon man's will into a highly organized stable one ${ }^{10}$. An important milestone on this way is creation of new technologies for strategic planning of the future.

\section{Management System Challenges}

The greatest attack on the well-being of the 20 century's management systems was delivered by the economic crisis of 2008 and its later repercussions. This unpredicted crisis was the one to reveal the instability of the traditional management systems along with the irrationality and inefficiency of the made decisions. According 
to V.E. Lepsky, it was to a great extent caused by a wide range of various factors developed during the last decades ${ }^{11}$ :

- "abrupt rise in the social processes' dynamics;

- high speed of knowledge development, causing fast turnover of social institutions and structures applying the knowledge, as well as relevant types and means of communications;

- decrease in the relevance of normative approach, when going beyond the standard actually becomes a standard;

- "blurring" of the conventional traditions and abrupt rise in the complexity of personal identification of administrative subjects of decision-making".

From this point of view, the main reason for the modern management systems' crisis is the new phenomenon in modern science related to the fact that "the reality certain management subjects deal with turns unobservable for classical science", though they have traditionally been the base for decision-making. In other words, scientific research cannot catch up with the dynamic development of the world, which is true for both traditional classical social science and their modern branches, such as secondorder cybernetics, synergy, cognitive approach, reflexive approach etc.

A significant role is also played by the globalization processes themselves, taking many decision-making processes, including the financial and economic one, from under legislative control of certain states. Globalization has created great new opportunities for the vast "freedom from" everything that used to be under control, opening larger spaces for making selfish decisions for various economic, financial and administrative elites, strengthening different forms of their social parasitism.

Sticking to such strategy, the decision makers are leading the whole humankind and themselves to the fast depletion of the planet's resources growth in the large-scale social socioquakes due to unequal distribution of the resources. According to a recent research ${ }^{12}$, keeping up with the tempo of the world development, consumption and distribution of benefits inevitably leads to the situation when the humankind follows many former civilizations that lived on the planet Earth but didn't survive to our days. Obviously, the former technologies of unlimited development of the world and all its parts are the greatest factors of global risk and shall be replaced with sustainable (or, to be more precise, supportive) development.

\section{Basics of Optimistic Strategies}

The list of today's global problems is so long that it can increase both enthusiasm of creators and pessimism of realists. In fact, within a short period of time, it is required to:

- increase efficiency growth at least by five times to provide decent life for everyone on the planet Earth ${ }^{13}$;

- increase the number of social, technical and technological innovations by several times to ensure growing economic efficiency and social stability, or, in other words, the running wheel of innovative creation needs to spin with greater speed;

- change the management systems to ensure sustainable development supporting the appropriate living standards for everyone on the planet Earth;

- preserve our common living space, the Earth, for future generations;

- create humanitarian basics for the optimistic development strategies ${ }^{14}$.

Evidently, such objectives and tasks need to be included into short-term development strategies of certain economic branches and states, including Russia, in one way or another. However, it takes compatible values and high level of mutual trust, 
which is a serious problem at the current stage of the world development and, unfortunately, is not yet present in the current Russian development projects. This far, they are dominated with the historically significant objective of catchingup development, which loses its point in the paradigm of the new technological development wave, the fourth industrial revolution, creating the threat of large-scale economic and social consequences requiring rapid development (outlined in a very approximate terms) of the management systems, economy and society as a whole. It raises the necessity to update the new education that has appeared on the surface and to prepare several generations for the new changing reality ${ }^{15}$. Actually, it is the beginning of a new era, the era of adaptation; it should be taken into account in the current development strategies right now. They need to adapt to the challenges of the new time.

Any strategy that claims to be positively efficient is based on the activity of people who see their self-fulfilment not in the present, but in the future. From the philosophical point of view, such people are the followers of indeterminism theory. They take the world as a world where the future is not predetermined, and where people can create it themselves, developing optimistic strategies of the future, and forming realistic projects on their basis. Such people have lively fantasy, they are inventive and persistent in reaching their goals. Depending on their political and emotional relations, they can be referred to in many possible ways: people striving for innovations, revolutionaries, reformers, the people of change. The executability of any modernization strategy directly depends on their number, activeness and creativity. In the project "Perspectives on Global Change: the TARGETS Approach"16 such people were referred to as individualists. Their main peculiarities were their commitment to creative initiative, inventiveness and opportunity of nature recovery. All arising problems, from social to environmental, can be always overcome with the help of new technologies. According to this approach, the individualists are opposed by egalitarians, or the supporters of equality of man and nature, perceiving the world in a pessimistic way, sincerely convinced that the current problems can be resolved, and the country and the world as a whole can be saved only with the suspension of development and return to an environmentallyfriendly lifestyle. The supporters of compromise and outer regulation, mostly consisting of the authorities, are called hierarchists; they suppose that the main factor of problem solving is partnership and optimal administration, capable of restricting the impact made on nature and selfish behaviour of man. This point of view, indeed, is typical of the administrative elite, and its vulnerable spot is the lack of understanding how such approach may ensure equation of resources, and how development strategies may regard the maximum motivation for the efficient performance. For this reason, any discussion of the future, the strategies and ways of achieving the desired goals either has distinctive traits of conflict of several opinions, a sort of opposition of "good" and "evil": "new" and "old", "future" and "improved past" with the expecting neutrality of a great number of the abstainer and excessive activeness of compromise-seekers and the outer assigned or delegated administrators.

The philosophical pictures of the world, and, consequently, the world outlooks are principally different for all these active groups of people, which makes them valuable and stable. It creates a hard problem: how to combine the incompatible, how to motivate the adherents of different worldviews and outlooks to search and find concord to implement the efficient development strategy and to achieve the desired result. In the end, the strategy needs to be a strategy, i.e. a long-term activity program with possible 
creative changes in the tactics of reaching the set strategical goal.

\section{Searching \\ for the Concord Procedure}

The eternal worldview struggle of "good" and "evil" can be avoided in several ways.

The first one is the most widely applicable in real Russian practice: to preserve only economic objectives and tasks, presenting social and humanitarian expectations in the most acceptable form for different groups of people. For many reasons, this technology has run dry, and new strategies are inevitably reaching the point where they change format to the one where human development indexes occupy quite a relevant place. However, this way causes new risks of worldview wars, inevitably turning into political conflicts. Development of the strategies demanded by the present age turns to be the politics' dole which can easily run into a dead end, which, basically, is what we are observing in contemporary Russia.

The second way consists of the creation of new communication technologies of future plan preparation. The main point is how to reach concord of different points of view concerning the renewal of the country within a historically short term (such as 15 years, until 2030, as Russian new development strategy authors take the courage to state).

It is also important to remark that the main protagonists of changing the pictures of the world and worldviews are the resourceful and independent innovators, and active supporters of compromise and negotiations between all existing parties. The people inclined to ringing alarm bells of change do not oppose decision-making anymore, but they became the key participants of the process. This triad of search, critical analysis and making a strategic decision concerning both the destiny of the whole country and its separate region, acts as a new mechanism for the management systems. To increase the level of trust and readiness for cooperation, the strong and weak parts of each of the competing parties of the dialogue and the discussion of the prevalent picture of the world and action strategy should be universally known. Actually, we are speaking of creating a brandnew technology for coordination of the priority objectives and tasks in the country development against the background of real threat and potential benefits. The inevitable inclusion of humanitarian objectives into the development strategy obliges us to consider them when overcoming modern Russian development deficits, such as raising the interpersonal trust level ${ }^{17}$, expanding the actually sought for human capital (in psychological sense) ${ }^{18}$ and cultural capital which still stands in the background (customs, traditions, values) with the cultural values needed for modernization ${ }^{19}$. In fact, it may mean a certain aggregate of development strategies united with a mutually coordinated system of strategical priorities of development for the implementation of the aligned project of the future.

Obviously, such priorities shall become an integral part of modern education, since modern administrative decision-making technologies are the greatest deficit of education programs for the new generations of specialists in various spheres $^{20}$. Timely and professional training of a critical mass of people "bred for success" in the New World with different worldview and types of thinking is becoming the major geopolitical and strategic task of any developing modern state ${ }^{21,22}$. The presence of a relevant number of such people gives an opportunity to make real use of their knowledge, abilities and creativity to work out some realistic and positive development strategies both today and the new surprising future.

Today it is required for people of different opinions to make the first mutual steps towards a new format and vision of the development strategies for the country, the world and the people living in it. 
Moskvich, Yu.N., Viktoruk, E.N. (2010). Virtual'nye i real'nye liki innovatsionnykh liderov: Krasnoiarskie ozhidaniia I predely rosta. Nauchnoe, ekspertno-analiticheskoe i informatsionnoe obespechenie natsional'nogo strategicheskogo proektirovaniia, innovatsionnogo i tekhnologicheskogo razvitiis Rossii [Virtual and Real Faces of Innovative Leaders: Krasnoyarsk Expectations and Limits of Growth. Scientific, Expert, Analytic and Information Provision for National Strategic Project Design, Innovative and Technological Development of Russia], In Part 1. Collection of works. Institute of Scientific Information on Social Sciences of the Russian Academy of Sciences. Editorial board: Pivovarov, Yu.S. (editor in chief) and others. Moscow, P. 276-284.

2 Viktoruk, E.N., Moskvich, Yu.N. (2012). Kul'turnye i mental'nye zaprosy innovatsionnogo razvitiia i tsennosti studencheskoy molodiozhi. Chelovek: Obraz i suschnost'. Gumanitarnye aspekty: Ezhegodnik [Kultural and Mental Requirements of Innovative Development and Student Youth's Values. Human: Image and Essence. Humanitarian Aspect. Annual publication]. Institute of Scientific Information on Social Sciences of the Russian Academy of Sciences. Centre for humanitarian research information. Philosophy department. Edited by Skvortsov, L.V. Issue 6. Part 2. Moscow, 355-363. Issue: Molodye uchionye v sovremennoy Rossii [Young Scientists of Modern Russia], edited by Khlebnikov, G.B., Shkaev, D.G. In: Problemy Cheloveka series [Human Problems], 122-139.

3 Schwab Klaus. The Age of Adaptation. Available at: https://www.project-syndicate.org/commentary/technological-economic-transformation-by-klaus-schwab-2015-02?barrier=true.

4 Ansoff, I. (1989) Strategicheskoe upravlenie [Strategic Management]. Moscow: Ekonomika, 519 p.

5 Proekt Strategii sotsial'no-ekonomicheskogo razvitiia Krasnoiarskogo kraia do 2030 goda [Project "Social and Economic Development of the Krasnoyarsk Territory (Krai) to the Year 2030], available at: http://www.krskstate.ru/2030/plan.

6 Kolin, K.K. (2014) Global'nye ugrozy razvitiiu tsivilizatsii v XXI veke [Global Threats to Civilization Development of the $20^{\text {th }}$ Century] In Strategicheskie prioritety [Strategic Priorities], (1), 8-9.

7 Yuriev, A.I. (2002) Globalizatsiia kak novaia forma politicheskoy vlasti, izmeniaiuschaia cheloveka i miroporiadok. Rossiia. Planetarnye protsessy [Globalization as a New Form of Political Power, Changing the Man and the World Order. Russia. Universal Processes] / edited by V.Yu. Bol'shakov. Saint Petersburg: Saint Petersburg University Publishing House, 250.

8 Moskvich, Yu.N. (2014) Mertsaiuschie kartiny global'nogo mira kak iskushenie i vyzov dlia teoriy upravleniia [Flickering Pictures of the Global World as a Temptation and Challenge for Management Theories] XII All-Russian Council for Management Problems. ACMP-2014. Moscow, 7797-7802.

9 Crawford P. (1991) In the era of Human capital: The Emergence of Talent, Intelligence, and Knowledge as the Worldwide Economic Force and What it means to Managers and Investors. New York: Harper Business.

10 Moskvich, Yu.N. (2012). "Global'naia turbulentnost"” i put' k "Cheloveku razumnomu" ["Global Turbulence" and the Way to being "Homo Sapiens"], In Intellektual'nyy potentsial Sibiri dlia razvitiia Rossii: Filosofiia - Nauka - Obrazovanie: sbornik statey Vtoroy Vserossiyskoy nauchnoy konferentsii "Sibirskiy filosofskiy seminar" [Intellectual Potential of Siberia for the Development of Russia: Philosophy - Science - Education: collection of articles of the Second All-Russian Scientific Conference “Siberian Philosophic Seminar”]. Krasnoyarsk, Siberian Federal University, 147-149.

11 Lepskiy, V.E. (2010) Filosofiia upravleniia i razvitiia v kontekste nauchnoy ratsional'nosti (sub'ektno-orientirovannyy podkhod) [Management and Development Philosophy in the Scientific Rationality Context (Subject-Focused Approach), In Filosofia i upravlenie: problemy i strategii [Philosophy and Management: Problems and Strategies]. Russian Academy of Sciences, Institute of Philosophy: edited by V.M. Rozin. Moscow: Institute of Philosophy of Russian Academy of Sciences, 134-166.

12 Motesharrei Safa Rivas Jorge, Kalnay Eugenia. Human and nature dynamics (HANDY): Modeling inequality and use of resources in the collapse or sustainability of societies. Ecological Economics, 2014, 101, 90-102.

13 Weizsacker, E., Hargroves, C., Smith, M. et al. (2013). Faktor piat'. Formula ustoychivogo rosta: Doklad Rimskomu klubu [Factor Five: Transforming the Global Economy: Report to the Club of Rome]. Moscow: AST-PRESS KNIGA, 368 p.

14 Atkisson, A. (2012). Pover'te Kassandre. Kak byt' optimistom v pessimistichnom mire [Believing Cassandra. How to Be an Optimist in a Pessimist World]. Translation of the $2^{\text {nd }}$ English edition by Dediukhin, V.V., edited by Tarasova, N.P. Moscow: BINOM. Laboratoriia znaniy, $264 \mathrm{p}$.

15 Moskvich, Yu.N. (2016). Obrazovatel'naia strategiia nakanune novoy tekhnologicheskoy revoliutsii: rol' chelovecheskogo i kul'turnogo kapitalov v razvitii Rossii i eio regionov. Obrazovatel'nye strategii i initsiativy v etnokul'turnom razvitii regionov Bol'shogo Altaia: materialy mezhdunarodnoy nauchno-prakticheskoy konferentsii, Barnaul, 14 aprelia 2016 goda pod. red. I.R. Lazarenko [Education Strategy at the Forefront of a New Technological Revolution: the Role of Human and Cultural Capitals in the Development of Russia and its Regions. Educational Strategies and Initiatives in the Ethnocultural Development of the Bolshoy Altai Regions: proceedings of the international scientific and practical conference, Barnaul, April 14, 2016. Edited by I.R. Lazarenko]. Altai State Pedagogical University, 235 p.

16 Atkisson, A. (2012). Pover'te Kassandre. Kak byt' optimistom v pessimistichnom mire [Believing Cassandra. How to Be an Optimist in a Pessimist World]. Translation of the $2^{\text {nd }}$ English edition by Dediukhin, V.V., edited by Tarasova, N.P. Moscow: BINOM. Laboratoriia znaniy, $264 \mathrm{p}$.

17 Doverie i nedoverie v usloviiakkh razvitiia grazhdanskogo obschestva [Trust and Mistrust in the Development of Civilian Society] (2013), Edited by Kupreychenko, A.B., Mersiianova, I.V. Moscow: Higher School of Economics Publishing House, 564 p. ISBN 978-5-7598-1140-4.

18 Strategicheskaia psikhologiia globalizatsii: Psikhologiia chelovecheskogo kapitala [Strategic Globalization Psychology: Human Capital Psychology] (2006). Textbook. Edited by Doctor of Psychology, Professor, Yuriev, A.I. Saint Petersburg: Logos, 512 p.

19 Kuvshinova, O. (2016). V Rossii nachinaetsia kognitivnyy dissonans [There is Cognitive Dissonance Beginning in Russia], In Vedomosti (4092). 
20 Moskvich, Yu.N., Diev, V.S. (2013) Obrazovanie na puti k novym beregam: poisk otveta na global'nye vyzovvy [Education on the Way to New Achievements: Searching for Answer to Global Challenges], In Vestnik KGPU imeni V.P. Astafieva [Newsletter of Krasnoyarsk State Pedagogical University Named After V.P. Astafiev], 2(24), 14-24.

21 Moskvich, Yu.N. (2009). Obrazovanie i vospitanie v postindustrial'nom mire: trudnyy put' k novoy real'nosti [Education and Upbringing in Post-Industrial World: a Challenging Path to New Reality], In Kul'tura i etika novogo mira [Culture and Ethics of the New World]. Edited by Moskvich, Yu.N. Series: Actual Philosophy Library, Issue 6. Krasnoyarsk: Litera Print, 286. Available at: www.dialog21.ru

22 Moskvich, Yu.N. (2016). Obrazovanie i meniaiuschiesia kartiny mira: poisk prostranstv soglasiia radi buduschego. Obrazovanie i sotsializatsiia lichnosti v sovremennom obschestve: materialy X Mezhdunarodnoy nauchnoy konferentsii "Obrazovanie i sotsializatsiia lichnosti v sovremennom obschestve" [Education and Changing Picture of the World: Searching for Concord Spaces for the Future. Education and Personality Socialization in Modern Society: proceedings of the X International Scientific Conference "Education and Personality Socialization in Modern Society]. Editorial board of Krasnoyarsk State Pedagogical University named after V.P. Astafiev. Krasnoyarsk, 548 p.

\title{
Поиски нового видения стратегии для России: проблемы, ограничения и возможности
}

Ю.Н. Москвич

Красноярский государственный педагогический университет им. В.П. Астафьева Россия, 660049, Красноярск, ул. Ады Лебедевой, 89

\begin{abstract}
В статье проводится анализ и обсуждение новых ограничений возможностей эффективного прогнозирования и планирования будущего и использования традиционных технологий разработки стратегий развития, обусловленные высоким темпом генерации научных знаний и связанных с ним технологических изменений. Рассматриваются причины неустойчивости традиционных систем управления, иррациональности и неэффективности принимаемых управленческих решений. Предлагаются базовые основы оптимистических стратегий развития и необходимые для их создания процедуры согласования интересов.
\end{abstract}

Ключевые слова: стратегическое управление, системы принятия решений, видение будущего, картины мира, мировоззрение, технологическая револючия, модернизация образования, человеческий, сочиальный и культурный капитал.

Научная специиальность: 24.00.00 - культурология. 